\title{
Milli Eğitim Bakanlığı Tarafından Uygulanan Aday Öğretmen Yetiştirme Sürecine ilişsin Yapılan Çalışmaların Analizi*
}

\author{
Ekrem CENGiZ** $^{* *}$
}

Milli Eğitim Bakanlığı Tarafından Uygulanan Aday Öğretmen Yetiştirme Sürecine Ilişkin Yapılan Çalışmaların Analizi

Özet

Bu çalışmanın amacı "Aday Öğretmen Yetiştirme" sürecine ilişkin olarak yapılan akademik çalışmaları incelemektir. Bunun için bu konuda yapılan çalışmalar Ulusal Tez Merkezi, ULAKBiM SBV tabanı ve Google Akademik gibi veri tabanlarından "Aday Öğretmen Yetiştirme”, Aday Öğretmen MEB”, “Aday Öğretmen Uygulama Süreci" gibi anahtar kelimeler kullanılarak taranmıştır. Çalışma doküman incelemesi yöntemiyle yürütülmüş, veriler betimsel analiz ile analiz edilmiştir. İncelenen yayınlar veri toplama araçları, yayın türü, çalışma grubu/örneklem türü, araştırma yöntemi, kullanılan veri analiz yöntemleri vb. gibi farklı başlıklarda analiz edilmiştir. İncelenen çalışmalarda; makalelerin daha fazla yer aldığı, adaylık eğitimi almış farklı branşlardaki öğretmenlerin örneklem olarak seçildiği çıkan sonuçlar arasındadır. Danışman öğretmen ve okul yöneticilerinin de yer aldığı örneklemlerle de çalışıması, farklı veri toplama araçlarına daha fazla yer verilmesinin uygun olacağı şeklinde öneriler sunulmuştur.

Anahtar Kelimeler: Milli Eğitim Bakanlığı, Aday Öğretmen Yetiştirme Süreci, Betimsel Analiz
An Analysis of The Studies Conducted Related to Teacher Candidate Trainings That Are Applied by The Ministry of National Education

\section{Abstract}

The aim of this study is to examine the academic studies that were carried out related to of process "Prospective Teacher Training". For this purpose, the studies on the subject have been examined trough databases such as National Dissertation Centre, ULAKBIM SBV base and Google Academic using keywords such "Teacher Candidate Training", "Teacher Candidate MEB", "Teacher Candidate Training Application Process ". The study was conducted with document analysis method and the data were analyzed with descriptive analysis. The publications reviewed are data collection tools, publication type, study group / sample type, research method, data analysis methods used etc. have been analyzed in different headings. In the studies examined it was found out that, there are more articles in the studies examined, the teachers in different branches who have received candidate training are selected as samples. Suggestions have been made that it is appropriate to work with samples including supervisor teachers and school administrators, and to include more data in different data collection tools.

Key Words: Ministry Of National Education, Teacher Candidate Training Process, Descriptive Analysis

\section{Giriş}

Dünyada yaşanmakta olan ekonomik ve sosyal değişimler, yüksek kaliteli eğitimi her zamankinden daha önemli kılmaktadır (Musset, 2010). Dünyanın her yerinde, eğitim sistemlerini iyileş-

\footnotetext{
* Bu çalışma II. Uluslararası Öğretmen Eğitimi ve Akreditasyon Kongresinde sözlü bildiri olarak sunulmuştur.

**Ekrem CENGiZ, Dr., Mehmetçik Ortaokulu, ec385893@gmail.com, ORCID ID orcid.org/0000-0002-7620-9543
} 


\section{Ekrem CENGiZ}

tirmek isteyen ülkelerin, öğretmen başarısına, akademik başarı için önemli bir yürütücü güç olarak yatırım yaptığı görülmektedir (Darling-Hammond, Chung Wei ve Andree, 2010). Eğitimin bütün süreçlerinin işleyişi ve verilen hizmetin niteliğini belirleyen en önemli unsur öğretmendir (ilyas, Coşkun ve Toklucu, 2017). Öğretmenler okullardaki en önemli kaynak olduğundan, yüksek kaliteli bir eğitime ulaşmak için onlara odaklanmak önemlidir (OECD, 2005). Günümüzdeki öğretmenler, öğrencileri daha önce hiç olmadığı kadar ekonomik ve sosyal değişime, henüz yapılmamış işlere, henüz icat edilmemiş teknolojileri kullanmaya ve daha önce ortaya çıkmamış sosyal sorunları çözmeye hazırlamalıdırlar (Schleicher, 2016). Bir toplumda eğitim öğretimin başarısı pek çok faktörün yanı sıra öğretmenin başarısıyla da yakın ilişkili olduğu için başarılı bir eğitim öğretim sistemine sahip olabilmek için yüksek nitelikli ve iyi yetişmiş öğretmenlere sahip olmak önemlidir (Milli Eğitim Bakanlığı [MEB], 2017). Bu noktada öğretmenlerin hizmet öncesi eğitimleri sırasında iyi yetiştirilmeleri ve aldıkları eğitime uygun olarak kendi branşlarında çalışmaları öğretmenlerin bu rollerini yerine getirmede önemli bir etkendir (Azar, 2011). Ancak ilgili alan yazında öğretmen adaylarının hizmet öncesinde yeterli bir eğitim almadıkları ifade edilmektedir (Seferoğlu, 2004). Diğer taraftan öğretmenlerin göreve başlamadan önce aldıkları eğitimin, mesleğin tüm gereklerini yerine getirmede yetersiz kaldığı da ifade edilmektedir (Gökyer, 2012). Öğretmenlerin güçlü bir hazırlık sürecinden sonra mesleğe başlaması Türkiye'de öğretmen yetiştirme süreçleri ve eğitimde kalite için büyük önem arz etmektedir (ilyas vd., 2017). Dolayısıyla mesleki anlamda bir takım eksikliklerle göreve başlayan öğretmenlerin kendilerinden beklenen hedefleri yerine getirmeleri de zorlaşacaktır. Bu noktada ülkemizin de katıldığı matematik ve fen başarısının uluslararası düzeyde ölçüldüğü TIMSS (Trends in International Mathematics and Science Study) 2015 sonuçlarına göre Türkiye 4. sınıf düzeyi fen başarısında 47 ülke arasında 35. sırada, 8. sınıf düzeyi fen başarısında ise 39 ülke arasında 21. sırada yer almıştır. Yine TIMSS 2015 sonuçlarına göre Türkiye 4. sınıf düzeyi matematik başarısında 49 ülke arasında 36. sırada yer alırken, 8. sınıf düzeyi matematik başarısında ise 39 ülke arasında 24. sırada yer almaktadır (Polat, Gönen, Parlak, Yıldırım ve Özgürlük, 2016). Diğer taraftan bir başka uluslararası sınav olan PISA (Programme for International Student Assessment) 2015 sonuçlarına göre ise Türkiye sınava katılan 72 ülke arasında, fen okuryazarlı̆̆ı alanında 54. sırada, okuma becerileri ve matematik okuryazarlığı alanlarında ise 50. sırada yer almaktadır (Taş, Arıcı, Özarkan ve Özgürlük, 2016). Bu sonuçlara göre Türkiye'nin uluslararası sınavlardaki başarı seviyesinin istenilen düzeyde olmadığı görülmektedir. PISA VE TIMSS gibi uluslararası sınavlarda yüksek başarı elde eden ülkeler, öğretmenlerin hem mesleğe girmeden önce hem de kariyerleri boyunca uzmanlıklarını geliştirme konusunda kararlıdırlar (Darling-Hammond vd., 2010). Bu noktada ilgili alan yazında, Türkiye'de, aday öğretmenlere mesleki yardım ve destek sağlayacak bir kılavuz öğretmenlik sistemi olmadığından, söz konusu öğretmenlerin, özellikle mesleğin ilk yıllarında başlarının çaresine bakmak zorunda kaldıkları (Toker-Gökçe, 2013) belirtilmekte ve bunun olumsuz bir durum olduğu ifade edilmektedir. Çünkü öğretmenlik; doğası gereği, akademik temellerinin yanı sıra, büyük ölçüde iş başında geliştirilebilen bir meslektir (MEB, 2017). Öğretmen adayları eğitim fakültelerinde öğrenim görürken yada formasyon eğitimleri sırasında okul deneyimi ve öğretmenlik uygulaması kapsamında okullara gitmektedirler. Ancak bu uygulamanın son sınıfta yapılıyor 
olmasının Kamu Personeli Seçme Sınavı [KPSS] nedeniyle süreci olumsuz yönde etkilediği (Dönmez Usta ve Turan Gültepe, 2016), bu çalışmaların programın son yıllarında yer almasının, istenilen ölçüde uygulama imkânının olmamasının, uygulama öncesinde, sırasında ve sonrasında yeteri kadar yönlendirme ve gözlemin olmamasının (Eret Orhan, 2017) bu uygulamalarda ifade edilen problemler arasında yer aldığı belirtilmektedir. Öğretmen adaylarının hizmet öncesinde özellikle uygulamaya dönük olarak bu ve benzeri eksiklilerle mezun oldukları ilgili alan yazına dayanarak söylenebilir. Bu sebeple öğretmenlere, özellikle mesleğin başında, gereken mesleki yardımı vermek ve destek sağlamak önem kazanmaktadır (Toker-Gökçe, 2013). Yapılan araştırmalar, birçok öğretmenin yenilikçi ilkelere göre ders verebilmek için yoğun rehberlik ve desteğe ihtiyacı olduğunu göstermiştir (Borko, 2004). Bu noktada Milli Eğitim Bakanlığı [MEB]'nın, tüm bu süreçleri göz önünde bulundurarak öğretmen niteliklerini arttırmaya yönelik olarak son yıllarda yürürlüğe koyduğu en önemli faaliyet, ilk defa 2016 yılında başlatılan, aday öğretmen yetiştirme programıdır (MEB, 2017). Bu programın amacının, öğretmen adaylarını okul ve sınıf ortamıyla tanıştırarak, onlara okulun yapısı, eğitim öğretim faaliyetleri, okulu meydana getiren unsurları birinci elden gözlemleme fırsatı vererek öğretmenlik mesleğine ön hazırlık yapma fırsatı sunmaktır (Öğretmen Yetiştirme ve Geliştirme Genel Müdürlüğü[ÖYGEM], 2016). Bu programa göre Milli Eğitim Bakanlığı'na ilk kez atanan öğretmenler kendi istedikleri bir şehirde, belirlenen aday öğretmen yetiştirme programına göre altı ay boyunca sınıf içi ve okul içi gözlemler, okul dışı faaliyetler ve hizmet içi eğitimlerden oluşan toplam 654 saatlik bir eğitime tabi tutulacaklardır. Bu eğitim kapsamında aday öğretmenler, Ders Planlama/Hazırlık/Değerlendirme, Ders izleme/Ders Uygulama, Okul İçi Gözlem ve Uygulama, Okul Dışı Faaliyetler ve Kitap Okuma/Film İzleme gibi alt başlıklardan oluşan bir programa göre eğitimlerine devam edeceklerdir (MEB, 2016). Türkiye'de farklı boyutları da içerecek şekilde ilk kez yapılan bu uygulamada her aday öğretmene en az on yıllık mesleki tecrübeye sahip bir danışman (mentor) öğretmen verilmiştir. Danışmanlık (mentorluk), genellikle daha deneyimli öğretmenler tarafından yeni başlayan öğretmenlere sağlanan kişisel rehberlik olarak tanımlanır (Rockoff, 2008). Danışmanlık (mentorluk), etkili öğretmen yetiştirme programlarının önemli bir bileşeni olup, mentorlar yeni göreve başlayan öğretmenlere pratik bilgiler vererek, öğretmenlerin öğretim becerilerinin geliştirilmesine rehberlik eder, geri bildirim ve yansıtma için onlara fırsatlar sunar (California County Superintendents Educational Services Association [CCSESA], 2016). Dolayısıyla Türkiye'deki uygulama ile de her aday öğretmenin yetiştirme programında yer alan faaliyetleri yaparken danışman (mentor) öğretmeni ile görüş alışverişinde bulunulması istenmektedir. Çünkü PISA ve TIMSS gibi uluslararası sınavlarda çok yüksek düzeyde başarı elde eden ülkeler arasında yer alan Şangay'da, tüm öğretmenlerin mentorlarının olduğu belirtilmektedir (Jensen, 2012). Yine bu sınav sonuçlarına göre üst sıralarda yer alan Finlandiya'da öğretmenlerin kendi alanlarının yanı sıra içerik, pedagoji ve eğitim teorisi alanlarında yetişmelerine yardımcı olan deneyimli danışmanlarının olduğu ifade edilmektedir (Sahlberg, 2010).

Ülkemizde ilk olarak 2016 yılı Mart ayında başlanan aday öğretmenlik uygulamasında uygulamaya katılan öğretmenler istedikleri bir ilde bu çalışmayı yaparken, daha sonra Öğretmen Yetiştirme Genel Müdürlüğü [ÖYGM] (2017) tarafından yayınlanan genelgede “2017-2018 eğitim-öğretim yılında yapılacak olan yetiştirme sürecinde aday öğretmenler, bağımsız olarak ders, etüt, nöbet vb. 


\section{Ekrem CENGiZ}

görevler alacaktır" denilmekte ve bu uygulamanın öğretmenlerin atandıkları illerde yapılacağı belirtilmektedir. Diğer taraftan MEB tarafından III Milli Eğitim Müdürlükleri [MEM['ne 11.12.2017 tarihinde gönderilen resmi yazıda (MEB, 2017c) "2016 yılı Şubat ayı ve sonrasında kadrolu veya sözleşmeli olarak atanan tüm aday öğretmenlere "Aday Öğretmen Yetiştirme Programı" (654 saat) uygulanacaktır." denilmektedir. Bu genelgeye göre bundan sonra da MEB'na atanan tüm öğretmenlerin “Aday Öğretmenlik Uygulaması" na katılacakları söylenebilir.

Yukarıda ifade edildiği gibi ülkemizde aday öğretmenlik uygulaması 2016 yılı Mart ayında başlamış olup günümüzde de halen bu uygulama devam etmektedir. Dolayısıyla öğretmen yetiştirme alanında önemli bir konu olması sebebiyle bu uygulamayla ilgili olarak çok sayıda akademik çalışma yapılmıştır. Konuyla ilgili araştırmaların sayısının arttırımasının, farkı bölgelerden ve örneklemlerden elde edilecek sonuçların program geliştirme sürecine bilgi vermesi bakımından yararlı olacağı ifade edilmektedir (Ulubey, 2018). Bu bağlamda ilgili alan yazında Türkiye'nin farklı bölgelerinden farklı örneklemlerle yapılmış çok sayıda akademik çalışma mevcuttur. Dolayısıyla bu alandaki yapılmış olan tüm çalışmalar hakkında genel bir düşünceye sahip olabilmek için bu çalışmaların analiz edildiği çalışmalara ihtiyaç duyulmaktadır. Belirli bir alanda yapıımış çalışmaların sistematik bir şekilde bütüncül olarak ele alınmasıyla alandaki gelecek araştırmalara yöntem ve yönelim oluşturması beklenmektedir (Çalık ve Sözbilir, 2014). Bu noktada Türkiye'de "Aday Öğretmenlik Uygulaması" ile ilgili olarak şimdiye kadar yapılmış olan çalışmaların analiz edilmesinin bu alanda daha sonra yapılacak çalışmalara yol göstereceği düşünülmektedir. İçerik analizi çalışmaları alandaki boşlukları ve eksikleri göstermenin yanında yapılan çalışmaların niteliklerinin değerlendirilmesi ve kullanılabilirliği açısından da ilgili alan yazına büyük katkılar sağlayacaktır (Kanlı vd., 2014). Dolayısıyla bu çalışmanın amacı Türkiye'de ilk kez uygulanan "Aday Öğretmenlik Uygulaması" sürecine ilişkin olarak yapılan akademik çalışmaların analiz edilmesidir. Bu bağlamada aşağıdaki araştırma sorularına cevap aranmaktadır;

1- Ülkemizde aday öğretmenlik uygulaması alanında yapılmış araştırmalarda ne tür veri toplama araçlarına yer verilmiştir?

2- Ülkemizde aday öğretmenlik uygulaması kapsamında hangi tür çalışmalar yapıımıştır?

3-Ülkemizde aday öğretmenlik uygulaması kapsamında yapılan çalışmalardaki çalışma grubu/örneklem grubunu kimler oluşturmaktadır?

4- Ülkemizde aday öğretmenlik uygulaması kapsamında yapılan çalışmalarda hangi araştırma yöntemleri kullanılmıştır?

5- Ülkemizde aday öğretmenlik uygulaması kapsamında yapılan çalışmalarda hangi veri analiz yöntemleri tercih edilmiştir?

6- Ülkemizde aday öğretmenlik uygulaması kapsamında hangi yıllarda çalışmalar yapıımıştır? 
7- Ülkemizde aday öğretmenlik uygulaması kapsamında yapılan çalışmalarda hangi sonuçlar elde edilmiştir?

\section{Yöntem}

Bu çalışmada Türkiye'de ilk kez uygulanan "Aday Öğretmenlik Uygulaması” sürecine ilişkin olarak yapılmış olan akademik çalışmalar incelenerek analiz edilmiştir. Dolayısıyla bu amaca yönelik olarak bu çalışmada nitel araştırma yaklaşımı içinde yer alan doküman incelemesi yöntemi kullanılmıştır. Doküman incelemesi yazılı ve elektronik belgelerin incelenmesi ve değerlendirilmesi için sistematik bir süreçtir (Bowen, 2009).

\subsection{Verilerin Toplanması}

Bu çalışmada "Aday Öğretmenlik Uygulaması" ile ilgili olarak yapılmış olan çalışmalar farklı değişkenler açısından incelenmiştir. Bu araştırmada "Aday Öğretmenlik Uygulaması" süreci ile ilgili olarak 2016 yılı Mart ayından 2018 yılı Haziran ayı sonuna kadar yapılan çalışmalar (EK-1) incelenmiştir. Bu çalışmalara Ulusal Tez Merkezi, ULAKBiM SBV tabanı ve Google Akademik gibi veri tabanlarından "Aday Öğretmen Yetiştirme”, "Aday Öğretmen MEB”, “Aday Öğretmen Uygulama Süreci" gibi anahtar kelimeler kullanılarak ulaşılmıştır. Yapılan tarama sonucunda elde edilen çalışmalardan sadece bu uygulama ile ilgili olan 2016-2018 yılları arasında yapılmış olan akademik çaıışmalar bu araştırmaya dâhil edilmiştir. Bu uygulamadan önce (2016 yllından önce) yapılan hiçbir çalışma bu araştırmaya dâhil edilmemiştir. Çünkü daha önce yapılan çalışmalarda aday öğretmenler bu araştırmada ifade edilen bir adaylık sürecinden geçmemiştir. Yapılan tarama sonucunda toplam 27 akademik çalışmaya ulaşıımıştır. Ancak bu çalışmalardan bir adet doktora tezinin tam metnine ulaşılamamıştır. Ayrıca dört akademik çalışmanın ise aynı anda hem makalesine hem de tezine ulaşılmış olup, bu çalışmalarda sadece biri (makaleler) bu incelemeye dâhil edilmiştir. Bunların dışında bir çalışmanın ise hem makale hem de bildirisine ulaşılmış, bu çalışmalardan ise sadece makale bu araştırmaya dâhil edilmiştir. Dolayısıyla yukarıda ifade edilen dâhil edilme ve hariç tutulma kriterleri çerçevesinde bu araştırmada toplam 23 akademik çalışma incelenmiştir.

\subsection{Verilerin Analizi}

Bu araştırma kapsamında incelenen tüm çalışmalar veri toplama araçları, yayın türü, çalışma grubu/örneklem türü, araştırma yöntemi, kullanılan veri analiz yöntemleri, çalışmaların yapıldığı yıl ve çalışmaların sonuçları gibi farklı başıklar altında olmak üzere analiz edilmiştir. Bunun için çalışmada betimsel analiz kullanılmıştır. Betimsel analizde elde edilen veriler, daha önceden belirlenen temalara göre özetlenir ve yorumlanır (Yıldırım ve Şimşek, 2006, ss. 224). Bu çalışma kapsamında yer alan çalışmalardan 6 tanesi araştırmacı ve betimsel analiz konusunda uzman olan bir öğretim üyesi tarafından analiz edilmiş ve yapılan analiz sonuçlarının büyük oranda uyuştuğu (Altı çalışmanın beşinde aynı analiz yapılmıştır) görülmüştür. Bu aşamadan sonra diğer çalışmalar araştırmacı tarafından analiz edilerek bu analiz sonuçları şekillerle sunulmuştur. 


\section{Ekrem CENGIZ}

\section{3. Çalışmanın Geçerliliği ve Güvenirliği}

Bütün araştırmalar, etik ilkeler dâhilinde geçerli ve güvenilir bilgi üretmek kaygısı taşır (Merriam, 2009, ss.199). Nitel araştırmada hem güvenirlik hem de geçerlik için alınan bir takım önlemler vardır (Yıldırım ve Şimşek, 2006, ss.255). Bu çalışmada geçerlik için uzman incelemesine, benzer şekilde güvenirlik için tutarlık incelemesine ve araştırmadan elde edilen sonuçların ham verilerle karşılaştırılarak teyit edilmesi için teyit incelemesine başvurulmuştur. Bu çalışmada tarafsızlığı sağlamak için çalışma kapsamında incelenen araştırmalar liste (EK-1) halinde sunulmuştur.

\section{4. Çalışmanın Sınırlılı̆ıı}

Bu çalışmada Türkiye'de aday öğretmenlik uygulaması kapsamında yapılan akademik çalışmalar incelenmiştir. Elde edilen bulgular sadece bu çalışmaya belirli kriterlere göre dâhil edilen araştırmalarla ve araştırmalarda ifade edilenlerle sınırlıdır.

\section{Bulgular ve Yorum}

Bu bölümde araştırmaya dahil edilerek incelenen akademik çalışmalarda ulaşılan bulgular aşağıda sunulmuştur. Ülkemizde aday öğretmenlik uygulaması kapsamında yapılan çalışmalarda kullanılan veri toplama araçlarına ilişkin bulgular aşağıdaki Şekil 1'de verilmiştir.

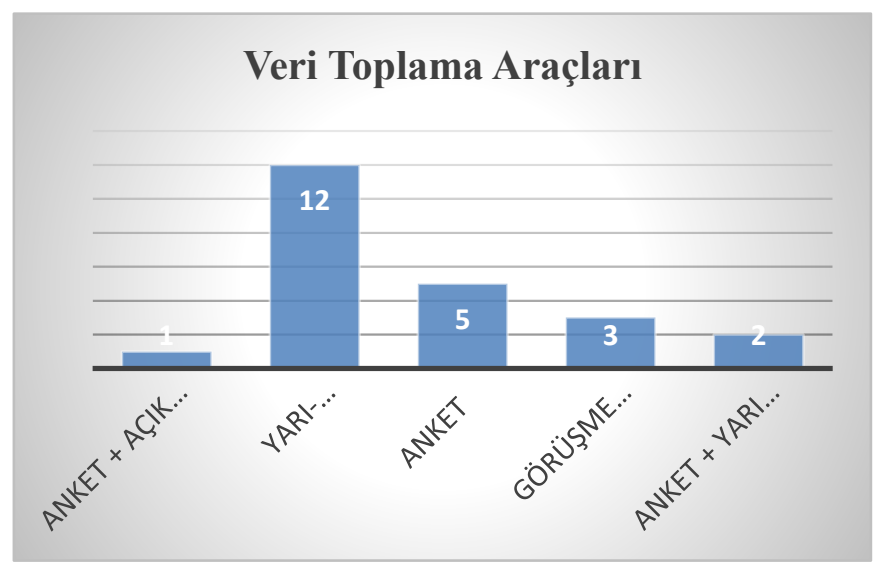

Şekil 1. Aday Öğretmenlik Uygulaması Kapsamında Yapılan Çalışmalarda Kullanılan Veri Toplama Araçları

Şekil 1'deki bulgulara göre aday öğretmenlik uygulaması kapsamında yapılan araştırmalarda kullanılan veri toplama araçları incelendiğinde en çok yarı yapılandırılmış görüşme formunun, en az ise anket ve açık uçlu anketin birlikte kullanıldığı görülmektedir. Diğer taraftan anket ve görüşme formunun da araştırmalarda veri toplama aracı olarak kullanıldı̆̆ı görülmektedir. Aday Öğretmen- 
lik Uygulaması kapsamındaki yapılan çalışmalardaki yayın türüne ilişkin analiz sonuçları aşağıdaki Şekil 2'de verilmiştir.

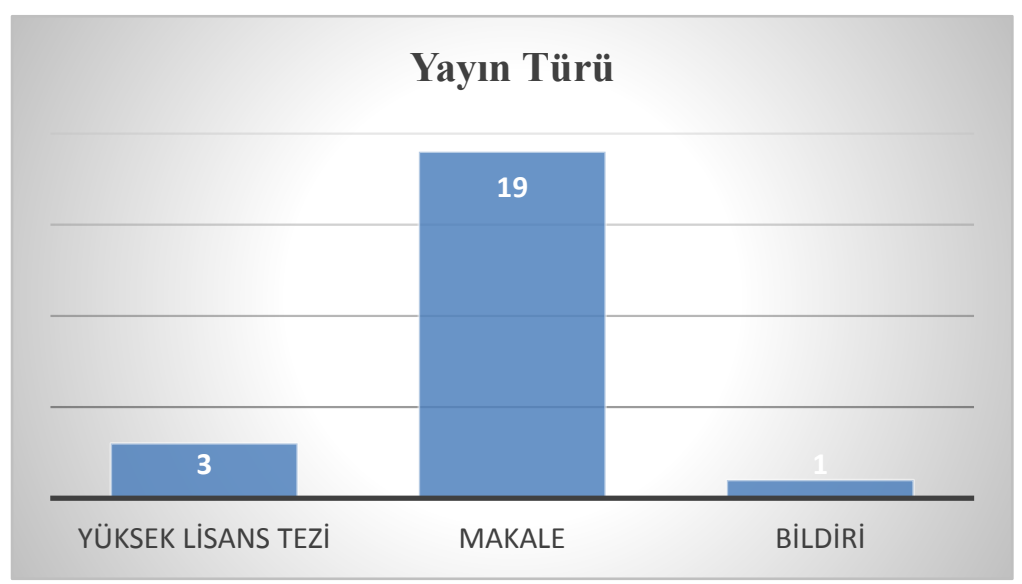

Şekil 2. Aday Öğretmenlik Uygulaması Kapsamında Yapılan Çalışmalardaki Yayın Türleri

Şekil 2'deki bulgulara göre aday öğretmenlik uygulaması kapsamında yapılan çalışmalar yayın türü açısından incelendiğinde en fazla çalışmanın makale olarak yapıldığı, en az çalışmanın ise bildiri türünden yayın olarak yapıldığı görülmektedir. Aday Öğretmenlik Uygulaması kapsamındaki yapılan çalışmalardaki çalışma grubu/örneklem grubuna ilişkin analiz sonuçları aşağıdaki Şekil 3’de verilmiştir.

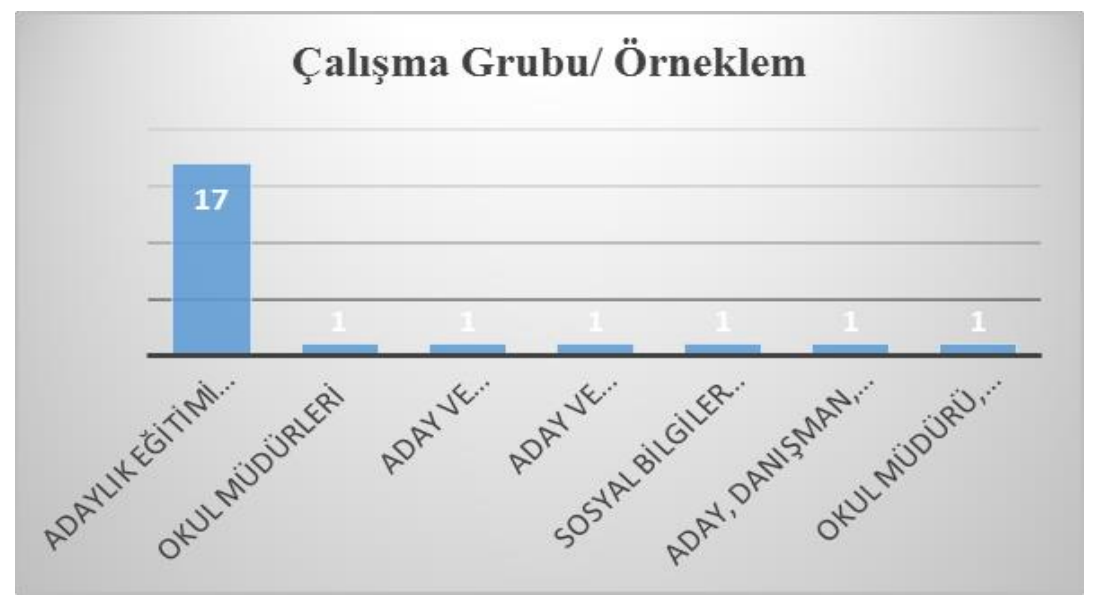




\section{Ekrem CENGIZ}

\section{Şekil 3. Aday Öğretmenlik Uygulaması Kapsamında Yapılan Çalışmalardaki Seçilen Çalışma Grubu/Örneklem}

Şekil 3'deki bulgulara göre aday öğretmenlik uygulaması kapsamında yapılan çalışmalarda en fazla aday öğretmenlik uygulaması alan farklı branşlardaki öğretmenlerin çalışma grubu olarak seçildiği görülmektedir. Diğer taraftan aday öğretmenlik uygulamasının yapıldığı okul müdürleriyle, aday ve danışman öğretmenlerle, aday ve danışman sınıf öğretmenleriyle, aday öğretmen, danışman öğretmen il- ilçe yöneticileri, maarif müfettişleri ve okul yöneticilerinin de katıldığı bir örneklem grubuyla ve okul müdürü, aday öğretmen danışman öğretmen ve ilçe koordinatörünün de katıldığı çalışma grupları ile de birer çalışma yapılmıştır. Aday öğretmenlik uygulaması kapsamındaki yapılan çalışmalardaki kullanılan araştırma yöntemlerine ilişkin analiz sonuçları aşağıdaki Şekil 4'de verilmiştir.

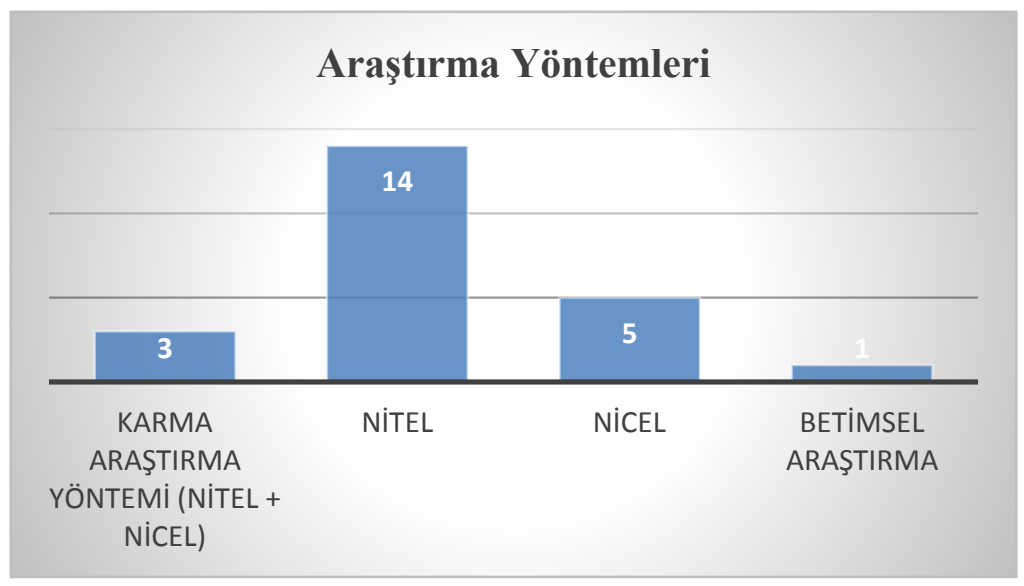

Şekil 4. Aday Öğretmenlik Uygulaması Kapsamında Yapılan Çalışmalarda Kullanılan Yöntemler

Şekil 4'deki bulgulara göre aday öğretmenlik uygulaması kapsamında yapılan çalışmalarda en fazla nitel araştırma yöntemlerinin tercih edildiği, en az ise betimsel araştırma yönteminin tercih edildiği ortaya çıkmıştır. Bunun yanında nicel araştırmanın ve karma araştırma yöntemlerinin de tercih edildiği çalışmalarda yapılmıştır. Aday Öğretmenlik Uygulaması kapsamındaki yapılan çalışmalardaki kullanılan veri analiz yöntemlerine ilişkin analiz sonuçları aşağıdaki Şekil 5'de verilmiştir. 


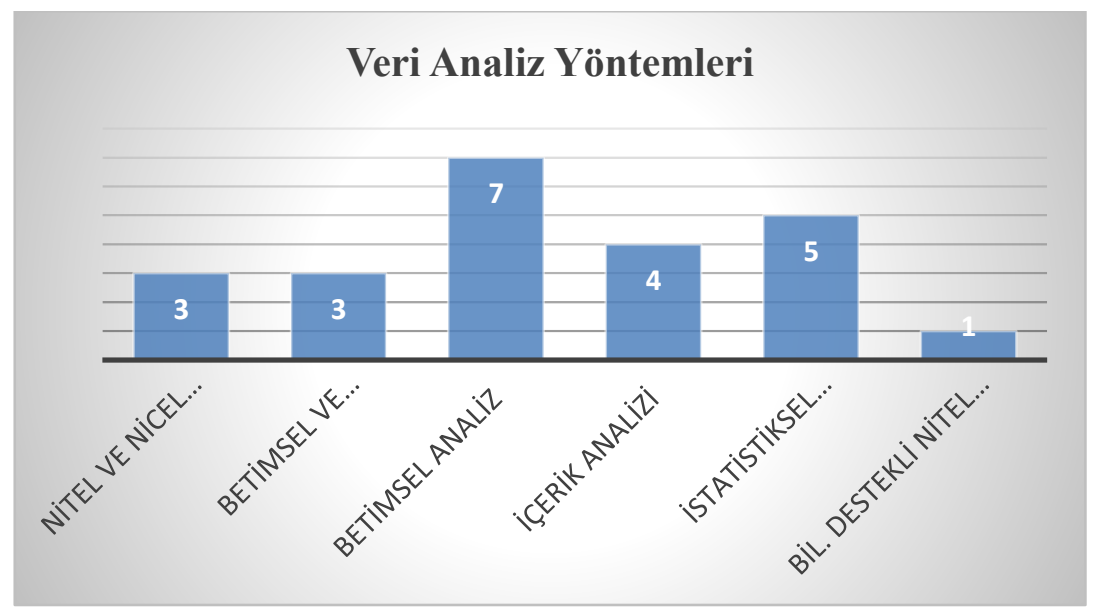

Şekil 5. Aday Öğretmenlik Uygulaması Kapsamında Yapılan Çalışmalarda Kullanılan Veri Analiz Yöntemleri

Şekil 5'deki bulgulara göre aday öğretmenlik uygulaması kapsamında yapılan çalışmalarda en fazla betimsel analizin, en az ise bilgisayar destekli nitel analizin kullanıldığı görülmektedir. Buna göre incelenen çalışmalarda nitel araştırmalarda kullanılan veri analiz yöntemlerinin daha fazla kullanıldı̆̆ı ortaya çıkmıştır. Bunun yanında beş çalışmada ise istatistiksel analizin, üç çalışmada nitel ve nicel analizin beraber kullanıldığı görülmektedir. Aday Öğretmenlik Uygulaması kapsamında hangi yıllarda çalışmaların yapıldığına ilişkin analiz sonuçları aşağıdaki Şekil 6 'da verilmiştir.

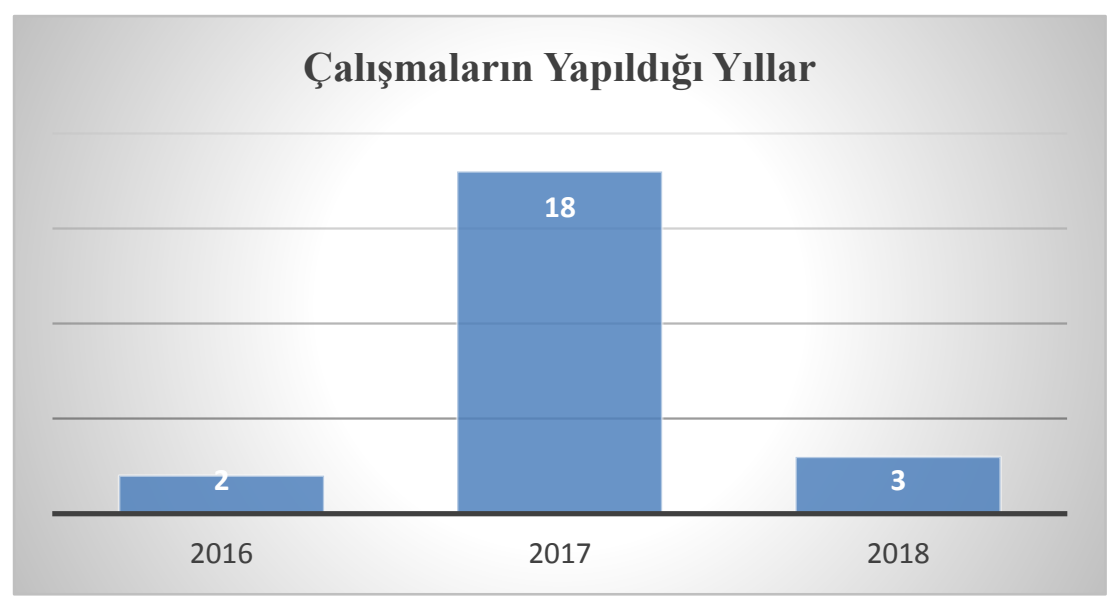

Şekil 6. Aday Öğretmenlik Uygulaması Kapsamındaki Çalışmaların Yapıldığı Yıllar 


\section{Ekrem CENGiZ}

Şekil 6'daki bulgulara göre aday öğretmenlik uygulaması kapsamında en fazla çalışmanın 2017 yılında, en az çalışmanın ise 2016 yılında yapıldığı görülmektedir. 2018 yılında ise sadece üç çalışma yapılmıştır.

Aday Öğretmenlik Uygulaması kapsamında yapılan araştırmalarda ulaşılan sonuçlar aşağıdaki Tablo 1'de sunulmuştur.

Tablo 1. Çalışma Kapsamında İncelenen Araştırmalardan Elde Edilen Sonuçlar

Çalışmalardan Elde Edilen Sonuçlar

Çalışma No

Danışman öğretmenler bu uygulamada gönüllü olup, uygulama ile aday öğretmenlerin mesleki gelişimlerine

$1,8,23$

katkı sağlamaktadır.

Danışmanlık programı yüksek düzeyde amacına uygun şekilde yürütülmüştür.

Danışman öğretmenlere göre adaylık sürecinde verilen eğitim onların üniversitede öğrendiklerini gerçek hayatla

yüzleştirmelerine yaramaktadır.

Bu uygulama alanındaki uzman kişilerle aday öğretmenlerin bilgi alışverişine imkan tanır

Uygulama aday öğretmenlere sınıfta gerçekleşen her türlü öğrenci- öğretmen etkileşimini gözlemleme firsatı

sunar.

Programda yer alan okul içi, okul dışı ve hizmet içi eğitim faaliyetleri büyük oranda gerçekleştirilmiş olup, bu

faaliyetler aday öğretmenlerin mesleki gelişimine katkı sağladı.

Bu uygulamada en büyük sorun aday öğretmenlerin çok sayıda form doldurmasıdır.

Aday öğretmen yetiştirme programının süresi ve içeriği yeterlidir.

Formlar, bazı olumsuz yanlarına rağmen genel olarak faydalıdır.

Aday öğretmenler, adaylık programının mesleki gelişimleri açısından katkı sağlayıp sağlamadığı hakkında farklı

görüşlere sahiptirler.

Aday öğretmenler bu program sayesinde, öğretimin yönetimi, sınıf yönetimi ve okulunu işleyişi başta olmak üzere, öğretmen ve yönetici olarak okulda üstlenecekleri görevlere yönelik deneyim elde etmişlerdir. 
Tutum Ölceği”" gelistirilmistir.

Aday öğretmenler aday öğretmenlik süreci ile ilgili olumlu görüşlere sahiptirler. dirmektedir.

Adaylar, adaylık eğitiminin kendilerine oldukça önemli deneyimler kazandırdığını, doğrudan kazanımlar yanında dolavlı vararlar sağladığını dile getirmislerdir.

Aday öğretmenler, adaylık eğitiminin en çok sınıf yönetimi konusunda kendilerine fayda sağladığını ifade etmiş-

lerdir.

Aday öğretmen yetiştirme sürecine ilişkin görüşlerin belirlenmesini sağlayacak 16 maddeden oluşan bir ölçeğin geliştirilmesi.

Aday öğretmenlerin uygulamanın süresine ilişkin farklı düşünceleri vardır.

Aday öğretmenlerin çoğu bu uygulamanın devam etmesini istemektedir. çıkarmak bu süreçte gereksiz olan uygulamalardır.

Adaylık eğitimini farkıı bir ilde almaya ilişkin öğretmenlerin hem olumlu hem de olumsuz görüşleri vardır. uyum sorunları yaşamalarına sebep olmuştur. 


\section{Ekrem CENGIZ}

Aday öğretmenlerin usta çırak ilişkisi ile adaylık sürecinde eğitimden geçmeleri ve danışman öğretmenleri nezaretinde derslere girmeleri yapılan bu uygulamanın olumlu yönleridir.

Aday öğretmenlerin bu uygulamanın kişisel gelişime katkı, motivasyon sağlama, mesleğe karşı ilgiyi arttırmaya katkıları ile ilgili olarak kararsız oldukları belirlenmiştir.

Aday öğretmenlik eğitim sürecinin atama yapılan okulda ya da atama yapılan okula benzer özelliklere sahip bir okulda yapılması ve sürecin kesinlikle birleştirilmiş sınıfları gözlemlemeyi de içermesi gerekmektedir.

Adaylık eğitimi özgüven sağlama, sınıf yönetimi, planlama, materyal tasarlama, müfredat, iletişim ve etkileşim boyutlarında adaylara gelişim imkânı sunmuştur.

Adayların dışlanması, öğretmen muamelesi görmemesi, toplantılara alınmaması, boş derslere görevlendirilmesi ve tek bir sınıfta gözlem yapma mecburiyetinde bırakılması.

Bu uygulamanın çoğu danışman öğretmen tarafından uygun görülmemesi.

Adaylık süreci uygulamasına katılanların il dışında görev tercihi yapabilmelerini okul yöneticilerinin yarısının uygun görmesi diğer yarısının uygun görmemesi.

Adayların çoğunun atamalarının yapıldığı yer dışında görev tercihi yapabilmelerini olumlu bulmaları.

Bu süreçte aday öğretmenin öğrenciyle yeteri kadar etkileşime girememesi, sürekli farklı sınıflarda derse girilmesi, danışman öğretmenin aday öğretmeni işini kolaylaştıran kişi olarak görmesi, öğrencilerin aday öğretmeni öğret men olarak görmemesi ve aday öğretmenin pasif konumda kalması.

Yöneticilerin adaya verecekleri eğitime dair bilgi sahibi olmaması, yöneticilerin adayları ilave iş gücü olarak görmesi, yöneticilerin aday eğitimine yönelik bir plan ve programa sahip olmaması ve yöneticilerin adaylara karşı takındığı sert tavır ve tutumlarının var olması.

Aday öğretmenlerden bazı kamu kurumlarını kendi başlarına ziyaret etmesinin istenmesi, ziyaretler sırasında organizasvon eksikliklerinin var olması.

Hizmet içi eğitim faaliyetlerinde anlatılan konu, anlatan kişi ve zaman ile ilgili bazı sorunların olması. tadır. 


\section{Sonuç, Tartışma ve Öneriler}

Geçmişten bugüne kadar hayata geçirilen reform projeleri dikkate alındığında, dünyadaki eğitim sistemlerinin başarısının, değişimi okuma ve değişime hızlı cevap verme ekseninde, öğretmenlerin kapasitelerinin bu yönde geliştirilmesine bağlı olduğu görülmektedir (MEB, 2017). Öğretmenler reform girişimlerinde başarının anahtarıdır, çünkü onlar son olarak bu girişimleri sınıf içinde gerçekleştirmekten sorumlu olan kişilerdir (Guskey, 2002). Eğitim kalitesi hiçbir zaman öğretim ve öğretmenlerin kalitesini aşamaz (Schleicher, 2016). Öğretmene ve öğretmen yetiştirmeye gerekli önemin verilememesi niteliksiz öğretmenlerin sisteme girdi olarak girmesini beraberinde getirecek ve bu durum bir bütün olarak eğitim sistemini olumsuz yönde etkileyeceği için kişisel ve mesleki anlamda pek çok özelliğe sahip öğretmenlerin yetiştirilmesi gerekmektedir (Aslan ve Sağlam, 2018). Bu kapsamda ülkemizde de MEB'na atanan tüm öğretmenlere “Aday Öğretmenlik Uygulaması" adı altında bir program uygulanmıştır. Bu çalışmada Türkiye'de ilk kez uygulanan "Aday Öğretmenlik Uygulaması" hakkında yapılan akademik çalışmalar incelenerek analiz edilmiştir. Çalışma kapsamında elde edilen sonuçlar her bir araştırma sorusu altında ilgili literatür ışı̆̆ında aşağıda tartışılarak sunulmuştur.

Bu araştırma kapsamında incelenen çalışmalarda en fazla yarı yapılandırılmış görüşme formu kullanılmıştır. Saban vd. (2010) tarafından Türkiye'de eğitim bilim alanında nitel araştırma metodolojisiyle yapılan makalelerin incelendiği bir araştırmada veriler toplanırken en fazla görüşme ve yarı yapılandırılmış görüşmelerin kullanıldığı, Saban (2009) tarafından çoklu zeka konusunda yapılan araştırmaların incelendiği bir çalışmada ise verilerin toplanmasında en fazla görüşme ve gözlemin kullanıldığı ortaya çıkmıştır. Bu sonuçların bu çalışmadan elde edilen sonuçla uyumlu olduğu söylenebilir. Ancak ilgili alan yazında bu çalışmanın sonucuyla uyumlu olmayan çalışmalarda mevcuttur. Örneğin Doğru, Gençosman, Ataalkın ve Şeker (2012) tarafından fen bilimleri eğitiminde çalışılan yüksek lisans ve doktora tezlerinin incelendiği bir çalışmada en çok ölçek, anket ve testlerin kullanıldığı, Selçuk, Palancı, Kandemir ve Dündar (2014) tarafından Eğitim ve Bilim dergisinde yayınlanan araştırmaların eğilimlerinin incelendiği bir araştırmada en fazla tutum, algı ve kişilik testlerinin veri toplama aracı olarak kullanıldığı ifade edilmiştir. İslamoğlu, Ursavaş ve Reisoğlu (2015) tarafından yapılan FATiH projesi ile ilgili bir içerik analizi çalışmasında verilerin daha çok tutum ölçekleriyle, görüşmelerle ve anketlerle toplandığı ifade edilmiştir. Öte yandan Kanlı vd. (2015) tarafından yapılan fen ve matematik eğitimi araştırmalarının incelendiği bir çalışmada katıımcıların en fazla sırasıyla, başarı/yetenek testleri, anketler ve tutum ölçeklerini doldurduğu, araştırmacıların da en fazla mülakat formu doldurdukları ortaya çıkmıştır. Gül ve Sözbilir (2015) tarafından Türkiye'de biyoloji eğitimi araştırmalarının incelendiği bir çalışmada ise en fazla anket ve başarı testlerinin daha sonra ise görüşmenin kullanıldığı ortaya çıkmıştır. Erdoğan vd. (2015) tarafından öğretim programları ile ilgili öğretmen görüşlerini içeren çalışmaların analiz edildiği bir araştırmada en fazla anketin, daha sonra yarı yapılandırılmış görüşme formunun ve ölçeklerin kullanıldığı ortaya çıkmıştır. Göksu, Özcan, Çakır ve Göktaş (2014) tarafından yapılan Türkiye'de öğretim tasarımı ile ilgili yapılan çalışmaların analiz edildiği bir araştırmada ise en fazla başarı testinin, daha sonra ise görüşme formu, anket ve tutum testlerinin kullanıldığı ortaya çıkmıştır. Görüşme ile deneyimler, 


\section{Ekrem CENGiZ}

tutumlar, niyetler, zihinsel algılar ve tepkiler anlaşılmaya çalışılır (Yıldıım ve Şimşek, 2006, ss. 119). Dolayısıyla Türkiye'de ilk kez başvurulan bir uygulama hakkında öğretmenlerin görüş ve deneyimlerinin neler olduğu üzerine odaklanıldığı için bu veri toplama aracının daha fazla kullanılmış olduğu söylenebilir. Ayrıca bu analiz çalışması kapsamında incelenen araştırmalarda daha çok nitel araştırma yöntemleri tercih edilmiştir. Görüşmenin nitel araştırmada en yaygın olarak kullanılan veri toplama yöntemlerinden biri olması (Yıldırım ve Şimşek, 2006, ss. 119) bu araştırmanın sonucunu açıklar niteliktedir.

Bu çalışma kapsamında incelenen araştırmalarda makale sayısının tez ve bildiri sayısından daha fazla olduğu ortaya çıkmıştır. İslamoğlu vd. (2015) tarafından yapılan bir analiz çalışmasında da makale sayısı tez ve bildiri sayısından fazladır. Diğer taraftan Saban (2009) tarafından yapılan bir içerik analizi çalışmasında ise yüksek lisans tez sayısının makale sayısından fazla olduğu ortaya çıkmıştır. Bu çalışmada ortaya çıkan makale sayısının fazla olması, akademisyenlerin mesleki getirileri daha yüksek olan yayın türünde yayın yapmayı tercih etmeleri ile (İslamoğlu vd., 2015) ilişkili olabilir. Diğer taraftan bu çalışmada ortaya çıkan tez sayısının az olması ise bu uygulamanın hayata geçirilmesinin üzerinden çok fazla zaman geçmemiş olması ile ilişkili olabilir. Çünkü bir tezin hazırlanması yayın aşaması gelmesi için makaleye göre daha uzun bir zaman dilimine ihtiyaç vardır.

Bu çalışmada ortaya çıkan diğer bir sonuç ise, çalışmaların doğası gereği daha fazla aday öğretmenlerle yapılmış olmasıdır. Bu durum bu süreç hakkında deneyim sahibi olan kişilerin deneyimlerini incelemenin önemli olduğunun düşünülmesi ile ilişkili olabilir. Çünkü amaçsal örneklem çalışmanın amacına bağlı olarak bilgi açısından zengin durumların seçilerek derinlemesine araştırma yapılmasına olanak sağlar (Büyüköztürk vd., 2010, ss.90). Göktaş vd. (2012) tarafından Türkiye'deki eğitim teknolojileri alanındaki makalelerin incelendiği bir çalışmada örneklem olarak en fazla lisans öğrencileri ardından öğretmenler kullanımıştır. Kula-Wassink ve Sadi (2016) tarafından Türkiye'de fen bilimleri eğitimi yönelimlerinin belirlendiği bir çalışmada ise en fazla öğretmen adayları ile çalışıldığı ortaya çıkmıştır. Dolayısıyla seçilen örneklemlerin çalışılan konuyla ilişkili olduğu ve bu konular hakkında daha derin bilgi elde edilecek şekilde örneklemlerin seçildiği söylenebilir.

Bu çalışmada ortaya çıkan diğer bir sonuç ise incelenen araştırmalarda daha çok nitel araştırma yaklaşımının tercih edilmesidir. Kanlı vd. (2014) tarafından yapılan fizik eğitimi araştırmalarının içerik analizi çalışmasında, Gül ve Sözbilir (2015) tarafından yapılan biyoloji eğitimi eğilim araştırmasında, Erdoğan vd. (2015) tarafından yapılan öğretim programları ile ilgili bir içerik analizi çalışmasında en fazla nicel araştırma yöntemlerinin tercih edildiği ortaya çıkmıştır. Bu sonuçlar bu çaış̧madan elde edilen sonuçla farklılık göstermektedir. Göktaş vd. (2012) tarafından yapılan bir içerik analizi çalışmasında da nicel araştırma yöntemlerinin daha fazla tercih edildiği ortaya çıkmış olup bu durumun Türkiye'de nicel yöntemlerin çalışma sonuçlarını genelleme, geniş örneklemlere ulaşma, zaman ve maliyet bakımından sağladığı avantajlardan kaynaklanabileceği ifade edilmiştir. Nitel araştırmalarda en önemli amaçlardan biri araştırmaya dahil edilen bireylerin algılarının ve deneyimlerinin ortaya konulmasıdır (Yıldırım ve Şimşek, 2006, ss. 45). Dolayısıyla aday öğretmenlerle yapılan çalışmaların incelendiği bu araştırmalarda örneklem olarak daha fazla aday öğretmen- 
lerin seçilmiş olması ve nitel araştırmaların da daha fazla tercih edilmiş olması birbirini tamamlayan iki durum olarak düşünülebilir.

Bu analiz çalışması sonucunda incelenen araştırmalarda veri analizi için en fazla betimsel analizin kullanıldığı ortaya çıkmıştır. Diğer analiz yöntemleri ile beraber düşünüldüğünde nitel araştırma yaklaşımında kullanılan veri toplama araçlarına özgü analiz yöntemlerinin tercih edildiği söylenebilir. Bu durum çalışmalarda daha fazla nitel araştırma yönteminin seçilmesiyle ilişkili olabilir.

Bu çalışmada incelenen akademik çalışmaların en fazla 2017 yılında yapıldığı ortaya çıkmıştır. Bu durum Aday Öğretmenlik Uygulamasının 2016 yılı Mart ayında uygulamaya konulmasının ardından öğretmenlerin uygulamaya Temmuz ayı sonuna kadar devam etmesiyle ilişkili olabilir. Çünkü aday öğretmenlerin uygulama hakkında bir görüş bildirmesi için uygulamayı tamamlamaları gerekir. Bu durumda uygulamanın tamamlanması yaklaşık olarak yılın ikinci yarısını bulmuştur. Bu tarihten sonra ise yapılacak çalışmaların yayınlanması sonraki yıla kalmış olabilir. 2018 yıında az bir çalışmanın yapılması ise bu analiz çalışmasında incelenecek araştırmaların 2018 yılı Haziran ayına kadar yayınlanmış olması kriteri ile ilgili olabilir. Diğer taraftan aday öğretmenlik uygulamasının ilk duyurulduğu tarih olan 2016 yılı Mart ayından sonra ilk uygulamanın öğretmenlerin kendi istedikleri illerde yapılması, daha sonra ise bu uygulamanın öğretmenlerin atandıkları okullarda yapılması zaman içerisinde bu konuya olan ilgilinin azalmasına ve bu konuda yapılan çalışmaların sayısının düşmesine neden olmuş olabilir.

Bu çalışmada incelenen akademik çalışmalardan elde edilen sonuçlara bakıldığında, aday öğretmenlerin bu süreç boyunca mesleki tecrübe, sınıf içi iletişim, ders anlatma, problem çözme, idari işlerin uygulanışı hususlarında gerekli becerileri kazandıkları, danışman öğretmenlerin gönüllü olup ve bu uygulamanın aday öğretmenlerin mesleki gelişimlerine katkı sağladığını ifade etmeleri, programda yer alan okul içi, okul dışı ve hizmet içi eğitim faaliyetlerinin yüksek oranda gerçekleştirildiğinin ifade edilmesi, aday öğretmenlerin aday öğretmenlik süreci ile ilgili olumlu görüşlere sahip oldukları çıkan önemli sonuçlar arasındadır. Bu sonuçlar adaylık sürecine katılan öğretmenlerin yukarıda ifade edilen konular başta olmak üzere birçok konuda eksikliklerin olduğunu ve bu uygulama ile eksikliklerini tamamlama yoluna gittiklerini göstermektedir. iligili alanyazında danışmanlık (mentorluk) programlarının öncelikle bilgi/deneyim açı̆ıını kapatmaya yönelik algılanan bir ihtiyaçtan doğduğu ifade edilmektedir (Wang ve Odell, 2002). Diğer taraftan daha fazla danışmanlık uygulaması alan öğretmenlerin öğrencilerinin bu uygulamayı daha az alan öğretmenlerin öğrencilerine göre daha yüksek başarı elde ettikleri de belirtilmektedir (Rockoff, 2008). Danışmanlık uygulaması sayesinde göreve yeni başlayan öğretmenlerin ilk yıllarda karşılaştıkları zorluklarla mesleği bırakma ihtimalleri en aza indirilmiş olur (Schleicher, 2016). Gerek bu araştırmada analiz edilen çalışmaların sonuçları gerekse uluslararası düzeyde yapılan çalışmalar danışmanlık uygulamalarının öğretmenlerin mesleki yaşamları açısından çok önemli olduğunu ortaya koymaktadır. Eğitim araştırmacılarına göre Finlandiya eğitim sisteminin PISA ve TIMSS gibi sınavlardaki bu başarısı güçlü öğretmen yetiştirme stratejisine dayanmaktadır (Sahlberg, 2010). Dolayısıyla aday öğretmen yetiştirme uygulamasına aksayan yönlerinin düzeltilerek devam edilmesinin bu yönde atılan önemli bir adım olduğu söylenebilir. 


\section{Ekrem CENGiZ}

Bu çalışmadan elde edilen veriler ışığında aşağıdaki öneriler sunulabilir;

1- Bundan sonra yapılacak çalışmalarda yarı yapılandırımış görüşme dışında farklı veri toplama araçlarının da kullanılması,

2- Yapılacak çalışmalar arasında tezlere daha fazla yer verilmesi,

3- Aday öğretmenlik uygulamasının diğer paydaşları olan danışman öğretmen ve okul idarecileri ile daha fazla çalışma yapılması,

4- Bundan sonra yapılacak çalışmalarda farklı araştırma yöntemlerine daha fazla yer verilmesi,

5- Aday öğretmenlik uygulaması günümüzde devam etmekte olup, bu konu ile ilgili konunun farklı yönlerini içine alacak çalışmaların yapılmasına devam edilmesi,

6- Araştırmalarda elde edilen sonuçlara göre bu uygulamanın aksayan yönlerinin düzenlenerek tekrar uygulanıp, etkinliğinin değerlendirilmesine yönelik çalışmaların yapılması.

\section{Kaynaklar}

Aslan, M. ve Sağlam, M. (2018). Öğretmenlik uygulaması dersinin öğretmen adaylarının görüşlerine göre değerlendirilmesi. Hacettepe Üniversitesi Eğitim Fakültesi Dergisi, 33(1), 144162 doi: 10.16986/HUJE.2017030313.

Azar, A. (2011). Türkiye'deki öğretmen eğitimi üzerine bir söylem: Nitelik mi, nicelik mi? Yükseköğretim ve Bilim Dergisi, 1 (1), 36-38.

Borko, H. (2004). Professional development and teacher learning: Mapping the terrain. Educational Researcher, 33(8), 3-15.

Bowen, G.A. (2009). Document Analysis as a Qualitative Research Method. Qualitative Research Journal, 9 (2), 27-40. DOI 10.3316/QRJ0902027.

Büyüköztürk, Ş., Kılıç Çakmak, E., Akgün, Ö.E., Karadeniz, Ş., Demirel, F.(2010). Bilimsel Araştırma Yöntemleri (7. Baskı). Ankara: Pegem Akademi Yayıncılık.

California County Superintendents Educational Services Association (2016). Best Practices In Teacher and Administrator Induction Programs. http://ccsesa.org/wpcontent/uploads/2016/06/Best-Practices-in-Teacher-and-Administrator-InductionPrograms.pdf. 10.03.2019 tarihinde ulaşıldı.

Çalık, M ve Sözbilir, M.(2014). İçerik analizinin parametreleri. Eğitim ve Bilim, 39(174), 33-38. DOI: 10.15390/EB.2014.3412. 
Darling-Hammond, L., Chung Wei, R. \& Andree, A. (2010). How high-achieving countries develop great teachers. Stanford Center for Opportunity Policy in Education Research Brief, 1-8. https://edpolicy.stanford.edu/sites/default/files/publications/how-high-achieving-countriesdevelop-great-teachers.pdf. 10.03.2019 tarihinde ulaşıldı.

Dönmez Usta, N. ve Turan Güntepe, E. (2016). Okul deneyimi ve öğretmenlik uygulaması derslerine ilişkin öğretmen adaylarının görüşleri. Uluslararası Sosyal Araştırmalar Dergisi, 9 (42), 1214-1223.

Doğru, M., Gençosman, T., Ataalkın, A. ve Şeker, F. (2012). Fen bilimleri eğitiminde çalışllan yüksek lisans ve doktora tezlerinin analizi. Türk Fen Eğitimi Dergisi, 9 (1), 49-64.

Erdoğan, M., Güzle Kayır, Ç., Kaplan, H., Aşık Ünal, Ü.Ö. ve Akbunar, Ş. (2015). 2005 Yılı ve sonrasında geliştirilen öğretim programları ile ilgili öğretmen görüşleri; 2005-2011 yılları arasında yapılan araştırmaların içerik analizi. Kastamonu Eğitim Dergisi, 23(1), 171-196.

Eret Orhan, E. (2017). Türkiye'de öğretmen adayları aldıkları öğretmen eğitimi hakkında ne düşünüyor? Nitel bir araştırma. Eğitim ve Bilim, 42 (189), 197-216.

Guskey, T.R. (2002). Professional development and teacher change. Teachers and Teaching: Theory and Practice, 8(3/4), 381-389.

Göksu, İ., Özcan, K.V., Çakır, R. ve Göktaş, Y. (2014). Türkiye'de öğretim tasarımı modelleriyle ilgili yapılmış çalışmalar. Illköğretim Online, 13(2), 694-709.

Göktaş, Y., Küçük, S., Aydemir, M., Telli, E., Arpacık, Ö., Yıldırım, G. ve Reisoğlu, í. (2012). Türkiye'de eğitim teknolojileri araştırmalarındaki eğilimler: 2000-2009 Dönemi Makalelerinin İçerik Analizi. Kuram ve Uygulamada Eğitim Bilimleri, 12(1), 177-199.

Gökyer, N. (2012). Öğretmen adaylarının hizmet öncesi eğitimleri sürecinde derslerin işlenişine ilişkin görüşleri. Milli Eğitim Üç Aylık Eğitim ve Sosyal Bilimler Dergisi, 41 (196), 124-141.

Gül, Ş. ve Sözbilir, M. (2015). Biology education research trends in Turkey. Eurasia Journal of Mathematics, Science \& Technology Education, 11(1), 93-109.

Illyas, i.E., Coşkun, i. ve Toklucu, D. (2017). Türkiye'de Aday Öğretmen Yetiştirme Modeli: İleme ve Değerlendirme. SETA Yayınları:78, İstanbul.

İslamoğlu, H., Ursavaş, Ö.F. ve Reisoğlu, i. (2015). Fatih projesi üzerine yapılan akademik çalışmaların içerik analizi. Educational Technology Theory and Practice, 5(1), 161-183.

Jensen, B. (2012). Catching up: Learning from the best school systems in East Asia. Summary Report. Grattan Institute. https://grattan.edu.au/wp

content/uploads/2014/04/129_report_learning_from_the_best_main.pdf. 10.03.2019

tarihinde ulaşıldı. 
Ekrem CENGIZ

Kanlı, U., Gülçiçek, Ç., Göksu, V., Önder, N., Oktay, Ö., Eraslan, F., Eryılmaz, A. ve Güneş, B. (2014). Ulusal fen bilimleri ve matematik eğitimi kongrelerindeki fizik eğitimi çalışmalarının içerik analizi. Gazi Üniversitesi Gazi Eğitim Fakültesi Dergisi, 34(2), 127-153.

Komisyon (2017). “Türkiye'de Öğretmen Eğitimi ve İstihdamı: Mevcut Durum ve Öneriler” Raporu. Hacettepe Üniversitesi Eğitim Fakültesi. Ankara.

http://www.egitim.hacettepe.edu.tr/belge/OgretmenEgitimi-istihdam Raporu.pdf. 12.08.2018 tarihinde erişildi.

Kula Wassink, F. ve Sadi, Ö. (2016). Türkiye'de fen bilimleri eğitimi yönelimleri: 2005 ile 2014 yılları arası bir içerik analizi. Ilköğretim Online, 15(2), 594-614.

MEB. (2016). Aday öğretmen yetiştirme programı. http://oygm.meb.gov.tr/www/adayöğretmen-yetiştirme-sürecine-ilişkin-yönerge-ve-yetiştirme-programı/içerik/328,

(erişim tarihi: 15/05/2016).

MEB. (2018). Milli Eğitim Bakanlığı 2023 Eğitim Vizyonu. Ankara.

MEB. (2017a). Öğretmen Strateji Belgesi 2017-2013. Öğretmen Yetiştirime ve Geliştirme Genel Müdürlüğü. Ankara.

MEB. (2017c). MEB, Öğretmen Yetiştirme Genel Müdürlüğü. "Aday Öğretmen Yetiştirme Programı" konulu resmi yazı.

Merriam, S.B. (2009). Qualitative research: A guide to design and implemention. London. Sage Publications (Çev. Editörü: Selahattin Turan).

Musset, P. (2010). Initial Teacher Education and Continuing Training Policies in a Comparative Perspective: Current Practices in OECD Countries and a Literature Review on Potential Effects.

OECD Education Working Papers, No. 48, OECD Publishing. http://dx.doi.org/10.1787/5kmbphh7s47h-en.

OECD. (2005). Teachers matter: Attracting, developping and retaining effective teachers. Paris: OECD Publishing. https://www.oecd.org/education/school/34990905.pdf. 10.03.2019 tarihinde erişildi.

ÖYGM. (2017). Öğretmen Yetiştirme Genel Müdürlüğü. http://oygm.meb.gov.tr/www/19072017tarihinde-atamasi-yapilan-sozlesmeli-aday-ogretmenlerin-yetistirme-programi/icerik/433.

12.04.2018 tarihinde erişildi.

Polat, M., Gönen, E., Parlak, B., Yıldırım, A. ve Özgürlük, B. (2016). TIMSS 2015 Ulusal Matematik ve Fen Bilimleri Ön Raporu 4. ve 8. Sınıflar. Milli Eğitim Bakanlığı Ölçme, Değerlendirme ve Sınav Hizmetleri Genel Müdürlüğü. Ankara. 
Rockoff, J. (2008). Does mentoring reduce turnover and improve skills of new employees? Evidence from teachers in New York City. www0.gsb.columbia.edu/faculty/jrockoff/rockoff_mentoring_february_08.pdf. 09.03.2019 tarihinde erişildi.

Saban, A.(2009). Çoklu zekâ kuramı ile ilgili Türkçe çalışmaların içerik analizi. Kuram ve Uygulamada Eğitim Bilimleri, 9 (2), 833-876.

Saban, A., Koçbeker Eid, B. N., Saban, A., Alan, S., Doğru, S., Ege, İ., Arslantaş, S., Çınar, D. ve Tunç, P. (2010). Eğitimbilim alanında nitel araştırma metodolojisi ile gerçekleştirilen makalelerin analiz edilmesi. Selçuk Üniversitesi Ahmet Keleşoğlu Eğitim Fakültesi Dergisi, 30, 125-142.

Sahlberg, P. (2010). The Secret to Finland's Success:Educating Teachers. Stanford Center for Opportunity Policy in Education.

Schleicher, A. (2016). Teaching Excellence through Professional Learning and Policy Reform: Lessons from Around the World, International Summit on the Teaching Profession, OECD Publishing, Paris. http://dx.doi.org/10.1787/9789264252059-en.

Seferoğlu, S. S. (2004). Öğretmen yeterlikleri ve mesleki gelişim. Bilim ve Aklın Aydınlığında Eğitim, $58,40-45$.

Selçuk, Z., Palancı, M., Kandemir., M. ve Dündar., H. (2014). Eğitim ve bilim dergisinde yayınlanan araştırmaların eğilimleri: İçerik analizi. Eğitim ve Bilim, 39(173), 430-453.

Taş, U.E., Arıcı, Ö., Özarkan, H.B. ve Özgürlük, B. (2016). PISA 2015 Ulusal Raporu. Millî Eğitim Bakanlığı Ölçme, Değerlendirme ve Sınav Hizmetleri Genel Müdürlüğü. Ankara.

Toker Gökçe, A. (2013). Aday öğretmenlerin öğretme ve öğrenmeye yönelik yeterliklerine ilişkin yaşadıkları sorunlar. Eğitim Bilimleri ve Uygulama, 12 (23), 23-42.

Ulubey, Ö. (2018). Aday öğretmen yetiştirme programının değerlendirilmesi. Hacettepe Üniversitesi Eğitim Fakültesi Dergisi, 33(2), 480-502.

Wang, J. and Odell, S.J. (2002). "Mentored learning to teach according to standards-based reform: a critical review", Review of Educational Research, Vol. 72 No. 3, pp. 481-546.

Yıldırım, A. ve Şimşek, H. (2006). Sosyal Bilimlerde Nitel Araştırma Yöntemleri. (6. Baskı) Ankara: Seçkin Yayıncılık. 
Ekrem CENGIZ

\section{EK-1}

\section{İncelenen Çalışmaların Künyesi}

1- Türkiye'de 2016 Yılında Uygulanan “Aday Öğretmen Yetiştirme Programı” Uygulamasının Değerlendirilmesi. Yüzüncü Yıl Üniversitesi Eğitim Bilimleri Enstitüsü Eğitim Bilimleri Anabilim Dalı. Yüksek Lisans Tezi, Van.

2- Koç, S. ve Akran, K. (2017). The Perceptions Of Supervising Teachers on The Prospective-Teacher Training: A Phenomenographic Research. Journal Of Human Sciences, 14(1), 976-986. Doi:10.14687/Jhs.V14i1.4167.

3- Erçetin, Ş.Ş. ve Şayir, G. (2017). Aday Öğretmen Yetiştirme Sürecinin Değerlendirilmesine Yönelik Aday Öğretmenlerin Görüşleri. Cappadocıa Journal Of History And Social Sciences. Vol. 8.

4- Önder, E. (2018). Prospective teacher training program according to prospective teachers' opinions. Kuram ve Uygulamada Eğitim Yönetimi, 24(1), 143-189. doi: 10.14527/kuey.2018.004.

5- Aksu, H. H., ve Durmuş, T. (2017). Aday öğretmen yetiştirme sürecini değerlendirmeye yönelik ölçek geliştirme çalışması OPUS - Uluslararası Toplum Araştırmaları Dergisi, 7(13), 616-631.

6- Altıntaş, S. ve Görgen, i. (2017). “Aday Öğretmen Yetiştirme Sistemi Üzerine Aday Öğretmenlerin Değerlendirmeleri / Preservice Teachers' Reviews On Preservice Teacher Training System", TURKISH STUDIES -International Periodical For The Languages, Literature And History Of Turkish Or Turkic-, ISSN: 1308-2140, (Prof. Dr. Tahsin Aktaş Armağanı) Volume 12/6, ANKARA/TURKEY, Www.Turkishstudies.Net, DOI Number: Http://Dx.Doi.Org/10.7827/Turkishstudies.11559, P. 15-30.

7- Nevzat, G. (2017). Aday Öğretmen Yetiştirme Programına Yönelik Aday Öğretmen Tutum Ölçeği'nin Geliştirilmesi (AÖTÖ): Geçerlilik Ve Güvenirlik Çalışması, . Hitit Üniversitesi Sosyal Bilimler Enstitüsü Dergisi, 10(2), 1771-1798.

8- Gökulu, A. (2017). Aday Öğretmenlerin Türkiye'deki Aday Öğretmenlik Eğitim Süreci ille İlgili Görüşleri. International Journal Of Social Sciences And Education Research, 3(1), 111-123.

9- Gül, İ., Türkmen, F. ve Aksel, N. (2017). Aday Öğretmen Görüşlerine Göre Aday Öğretmen Yetiştirme Sürecinin Değerlendirilmesi, Hitit Üniversitesi Sosyal Bilimler Enstitüsü Dergisi, 10 (1), 365-388.

10- Gürsoy, G. ve Turan Özpolat, E. (2017). Aday Öğretmen Yetiştirme Sürecine Iliş̧in Görüş Ölçeği Geliştirme Çalışması. Diyalektolog Ulusal Sosyal Bilimler Dergisi, 14, 65-78. 
11- Kana, F. ve Yaşar, E. (2017). Aday Öğretmenlerin Aday Öğretmenlik Sürecine İlişkin Görüşlerine Yönelik Bir Durum Çalışması. Türk \& Islam Dünyası Sosyal Araştırmalar Dergisi, 4 (13), 164176.

12- D. Kılıç, Ö. Babayiğit, ve B. Erkuş. (2016). Aday Öğretmenlerin Adaylık Eğitimine Illişkin Görüşleri. EKEV Akademi Dergisi, Vol. 68, 81-92.

13- Kozikoğlu, ì. ve Soyalp, H. (2018). Aday Öğretmenlerin Danışman Öğretmenlerin Ve Okul Yöneticilerinin Aday Öğretmen Yetiştirme Programına Yönelik Görüşlerinin İncelenmesi. Hacettepe University Journal Of Education, Vol. 33, No. 4, 934-952.

14- Köse, A. ve Atalmış, E. H. (2017). Aday Öğretmen Yetiştirme Sürecinde Alınan Eğitimlerin Öğretmenlik Uygulamalarına Katkısı Sorunlar ve Çözüm Önerileri. Turkish Studies Educational Sciences, 12 (25), 491-512.

15- Köse, A. (2016). Okul Yöneticilerinin Görüşlerine Göre Aday Öğretmen Yetiştirme Sürecinin Değerlendirilmesi. Abant Izzet Baysal Üniversitesi Eğitim Fakültesi Dergisi, 16(3), 924-944.

16- Pala, A. (2017). MEB İlkokul Ve Ortaokul Eğitim Kurumlarına Atanan Aday Öğretmenlere Uygulanan Mentorluk Süreci. Gaziantep Üniversitesi Eğitim Bilimleri Enstitüsü, Eğitim Bilimleri Ana Bilim Dalı. Yüksek Lisans Tezi. Gaziantep.

17- Sarıkaya, İ., Samancı, O. ve Yılar, Ö. (2017). Aday Öğretmen Yetiştirme Sürecinin Aday ve Danışman Sınıf Öğretmenlerinin Görüşleri Kapsamında Değerlendirilmesi Bir Karma Yöntem Çalışması. Gazi Eğitim Fakültesi Dergisi, 37(3): 939-989.

18- Çakmak, Z., Kaçar, T. ve Arıkan, i. (2018). Sosyal Bilgiler Aday Öğretmenlerinin Aday Öğretmen Yetiştirme Sürecine Iliş̧kin Görüşleri. Turkish Journal Of Educational Studies, 5 (1), 58-82.

19- Tünay, T. (2017). MEB Aday Öğretmen Yetiştirme Süreci Uygulamasının Öğretmen Bakış Açısıyla Değerlendirilmesi. Karabük Üniversitesi Sosyal Bilimler Enstitüsü, İşletme Anabilim Dalı. Yüksek Lisans Tezi.

20- Topsakal ,C. ve Duysak, A. (2017). Aday Öğretmen Yetiştirme Sürecine ilişskin Aday Öğretmenler Ve Diğer Paydaşların Görüşleri. Sakarya University Journal of Education, 7 (3), 625-638.

21- Yılmaz, M. (2017). Aday Öğretmen Yetiştirme Sürecinde Karşılaşılan Sorunlar ve Çözüm Önerileri. 21. Yüzyılda Eğitim ve Toplum, 6 (16), 135-155.

22- Ulubey, Ö. (2018). Aday Öğretmen Yetiştirme Programının Değerlendirilmesi. Hacettepe University Journal Of Education, 33 (2), 1-23.

23- Çiftçi, C. (2017). Aday Öğretmenlerin Aday Öğretmen Yetiştirme Süreci İle İlgili Görüşleri. Uluslararası Öğretmen Eğitimi ve Akreditasyon Kongresi. 19-21 Mayıs 2017 İstanbul / Türkiye. 